\title{
THE GEORGIAN RESORTS AS A BASIS FOR WELLNESS TOURISM DEVELOPMENT
}

\author{
Mzia Tutberidze ${ }^{1}$
}

\begin{abstract}
Political, economic, social and ecological changes that have taken place in the world in recent decades have brought about the increase of population's demand for wellness tourism. At present, wellness tourism is the fastest growing and most significant segment of the world tourism industry, with double growth rate, compared with the growth rate of the tourism industry as a whole, each customer spending 53percent more than a typical international tourist. Though wellness tourism is a global phenomenon, its implementation is predominantly localized in the resorts with the appropriate natural conditions and infrastructure. Natural resources have been used in Georgia for health care and wellness since time immemorial. Based on the diversity of this country's natural conditions, 103 sites were given the legal status of resorts, and up 200 are defined as resort areas. Still, the awareness of Georgia's capacity in this aspect is low worldwide. Due to the crisis of the 1990-s and the civil war, part of the resorts were destroyed; another part is located in the occupied territories and to date is outside the Georgian government's jurisdiction. Though the industry's recovery began in the 2000-s, the pace of the health tourism's development lags behind that of other kinds of tourism. According to the infrastructure's present condition and developmental trends, four groups of resorts can be highlighted in Georgia. In the future, upgrading of the legal framework, further development of the resorts' infrastructure, targeted diversification of tourism products, more flexible, high-quality system of services, and improved resort management will create conditions for wellness tourism advancement in Georgia, which, in turn, will establish it in the world tourism industry.
\end{abstract}

Keywords: Georgia, health tourism, medical tourism, wellness tourism, resort, resort area.

\section{Introduction}

Georgia is positioned in the world tourist market as a country with landscape diversity, richness of natural resources and unique ethnic culture. Still, revealing its potential as a favorable place for health and wellness tourism will significantly expand and complement its image.

Travel for rest and health improvement is one of the oldest types of tourism. In Georgia, too, natural resources have been used for health care and wellness since time immemorial (e.g. in Abastumani, Borjomi, Tsqaltubo, etc.); 103 out of the world's 4000 resorts (Dracheva, 2008) are located here (namely, 44 climatic, 27 balneological, 2 - mud treatment and 30 mixed-type resorts). By the end of the 1980$\mathrm{s}$, Georgia was one of the Soviet Union's most significant resort regions, yielding only to Russia and Ukraine in the number of resorts and their carrying capacity, with its 120 thousand beds (Recreational, 1991). Processes that took place in the following decade, seriously impeded tourism development, just as other economy segments. In

\footnotetext{
${ }^{1}$ Department of Human Geography, Vakhushti Bagrationi Institute of Geography, Ivane Javakhishvili Tbilisi State University, Tbilisi, Georgia, mziatutberidze@ gmail.com
} 
the 2000s some revival of the field began, though compared to the other types of tourism, health tourism is developing rather slowly.

\section{Main text}

For years, tourism for health treatment and wellness, both based on use of natural resources were considered one single area, since their implementation was localized at the resorts.

Resorts are the basis of health and wellness tourism in any country. The term "health-wellness tourism" being frequently used in Georgia during the Soviet period and afterwards. In Soviet balneology, the concept of health tourism rested on 18, 21 or 24-day treatment course carried out in specialized pensions and sanatoriums.

Some authors use the term "resort tourism" meaning a purposeful journey to a resort for a comprehensive health treatment and rehabilitation in specialized centers in the lap of nature (Baklykov, 2003).

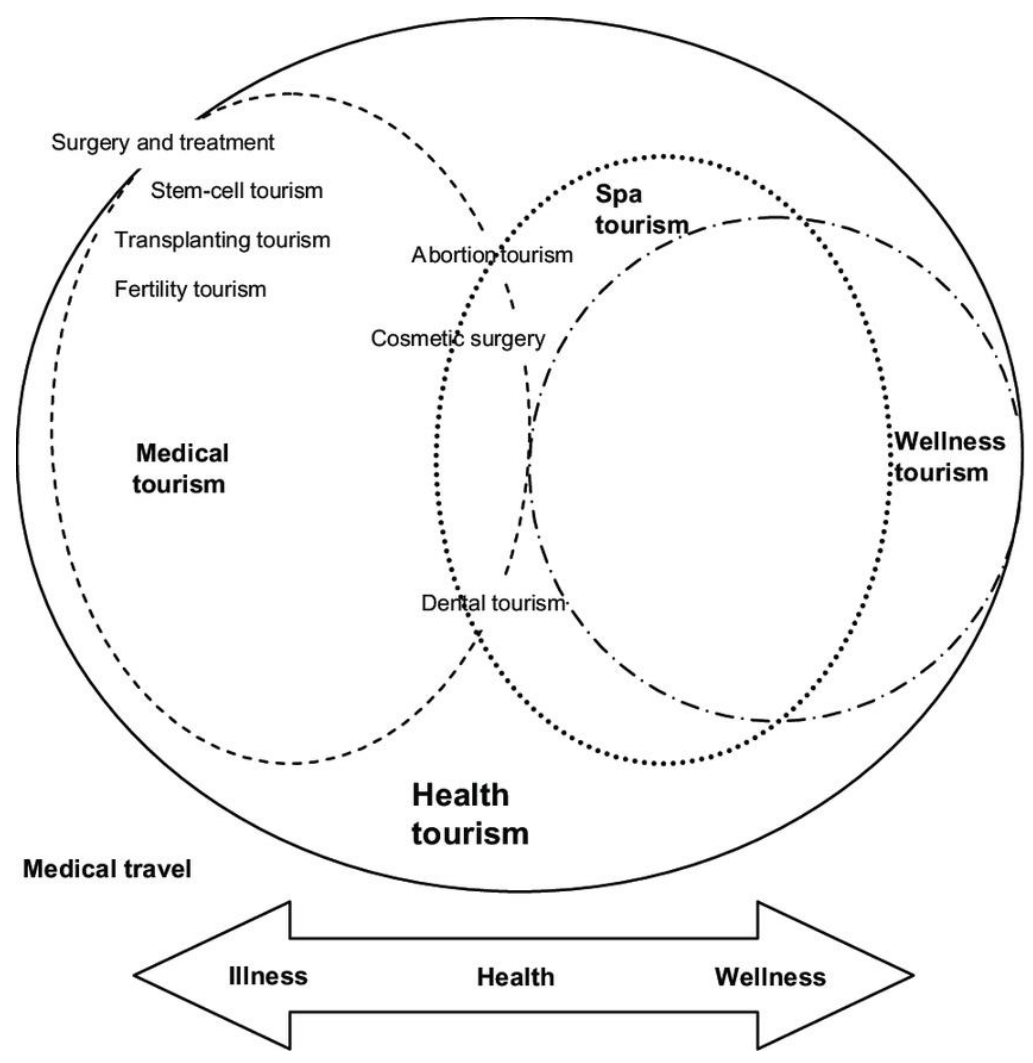

Fig.1 Interrelatedness of health, spa, wellness and medical tourism domains.

(Tourism in Russia, 2015). 
The overabundance of terms (treatment tourism, health tourism, resort tourism, sanatorium-resort tourism, clinical tourism, medical tourism) interferes with customer and management's clear understanding of the existing types of tourism.

Nowadays, the World Tourism Organization, researchers and specialists in the field of "health tourism" differentiate between "medical tourism" and "wellness tourism", according to the tourist group's target (https:/www.unwto.org/high-levelforum-medical-and-health-tourism). Moreover, there is a tendency to further segmentation. In medical tourism, for example, there are travelers that go straight to high-tech medical institutions to be treated by highly qualified personnel; or, the group that is at the crossroad of medical and wellness tourism- tourists that utilize natural resources (spa tourism) (Fig.1 ). In wellness tourism two groups are singled out; first, the tourists who choose the destination mainly for health purposes, and second, those who seek health maintenance and improvement independently of the travel destination.

Several factors influence population's growing demand for rest and wellness:

1. Population has changed demographic structure;

2. Broadening of the middle class;

3. Life acceleration and increase of stressful situations;

4. Ecology deterioration;

5. Popularity of wellness lifestyle;

6. Border opening and travelling alleviation (Dracheva, 2016; Nikitina, 2012).

As some authors point out, complex health treatment measures result in 1.7 times health level rise in the population. Natural factors' application increases treatment efficiency by 25-30percent and reduces treatment costs in hospitals and out-patient clinics by 10-15 percent (Nikitina 2012).

The most rapidly developing - wellness tourism is a volatile and complicated segment of world tourism industry. According to the Global Wellness Institute 2017 estimation, with US\$639 bln spent, this tourism segment shows 6.5 percent annual growth, which is twice as much as general tourism growth. In 2017, the world wellness tourism trips number was $830 \mathrm{mln}$, which exceeds the 2015 -year figures by $139 \mathrm{mln}$. It is noteworthy that the secondary wellness tourism accounts for 89percent of trips and for 86percent of expenditures (GWI 2018).

Generally, both domestic and international tourists spend much more for wellness tourism than other kinds of tourists, since the treatment a customer receives is only efficient when a particular course of treatment is taken, as a rule, not less than 10-14day long. All this makes these tourism segment customers high spenders. In 2017, wellness tourists spent average $\$ 1528$ for one trip, which is 53percent more than a typical international tourist's expenditures. A domestic tourist would spend $\$ 609$, which exceeds a typical domestic tourist's expenses by 178percent (GWI 2018). Noteworthy is that these expenditures are divided between several segments of tourism industry: accommodation, food, wellness treatment, health improvement procedures, sightseeing's, shopping and other.

Though the wellness tourism is a global phenomenon, as was already mentioned, it is generally localized at the resorts with appropriate natural conditions and infrastructure. 
Georgia's natural diversity, its healthy climate, the Black Sea coast with convenient beaches, abundance of hydrographic objects, over 2000 mineral springs of various chemical composition and different temperature, vast areas covered with forests, speleological objects, the abundance and variety of protected areas create the basis for organizing resorts with different medical profiles. The state of ecosystem and natural resources is of great importance for health tourism, as a nature-oriented field. The competitiveness of a tourist destination is based on combination of the existing natural conditions and quality infrastructure. That is what makes the leading companies in the field care so much about resource maintenance and sustainable development.

In Georgia, there are certain geographic regularities that characterize territorial structure of different type resorts, i.e., the majority of balneological and mud-therapy resorts are concentrated in the intermountain lowland, while climatic and mixed-type resorts are on the seashores or in the mountain foothills (Neidze at al. 2017).

In recent years, the resorts have undergone significant transformation caused by changes in touristic demands. Together with healthy lifestyle growing popularity, demand for wellness tourism increased among middle-age population who prefer active rest and are short of time. During last 25 years, traditional sanatorium treatment of advanced age customers was substituted by wellness procedures fit for vast groups of customers. Therefore, a traditional resort nowadays is not just a resting place for the senior population but rather a multifunctional wellness center designed for vast groups of population with various demands that functions round the year.

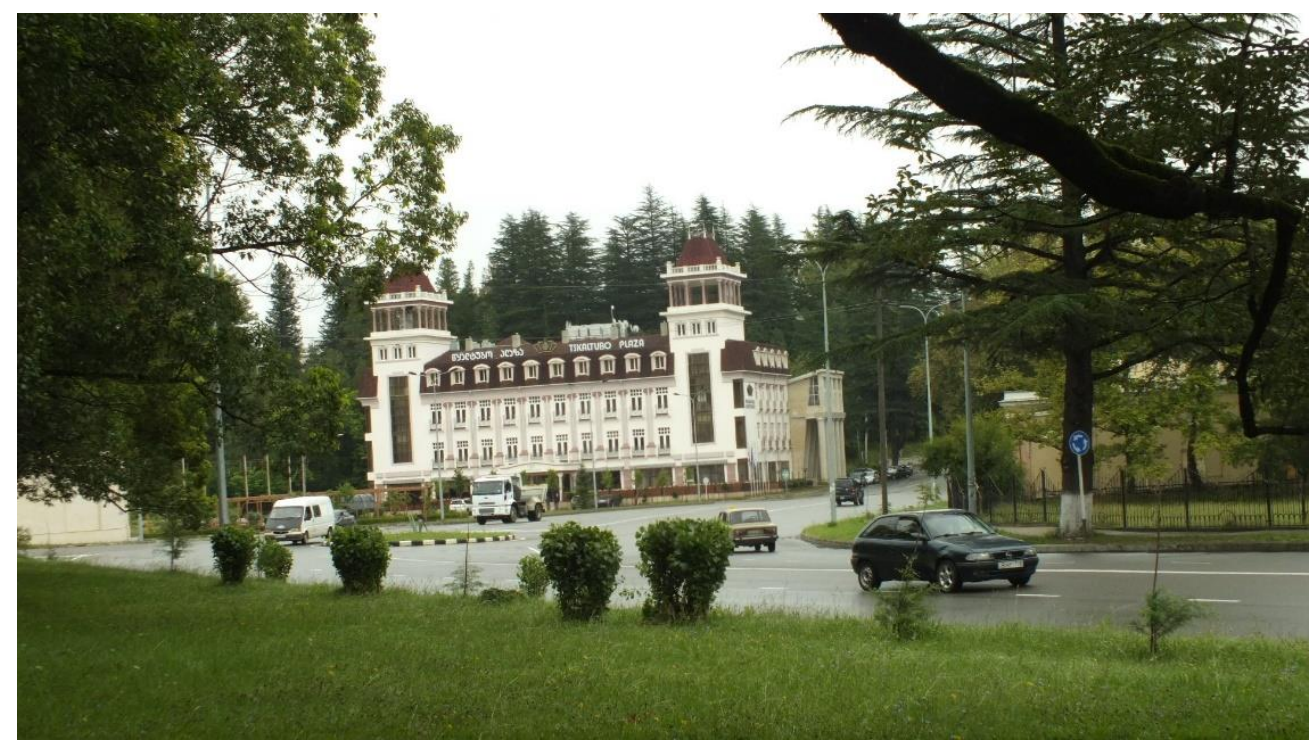

Fig.2 Resort Tsqaltubo (photo by M.Tutberidze).

The paradigm of sanatorium-resort service has changed in accordance with today's demands, and "hospital" service has been substituted by the treatment aimed at general health maintenance and improvement, with the increasing demand for complete rest and wellness. 
Transition from government-subsidized operating to self-financing in the postSoviet space (Georgia included) is yet another reason of the resorts' transformation. Prior to the collapse of communist regime, the state-run resorts were subsidized from the state budget and other non-centralized sources. Nowadays resorts management seek to diversify the products offered in order to attract new investments. To this intent, while maintaining the resort's curative functions, management organizes cultural and sport events, various health improvement and wellness procedures (anticellulite, anti-stress, phito-rejuvenation programs, and cosmetology).

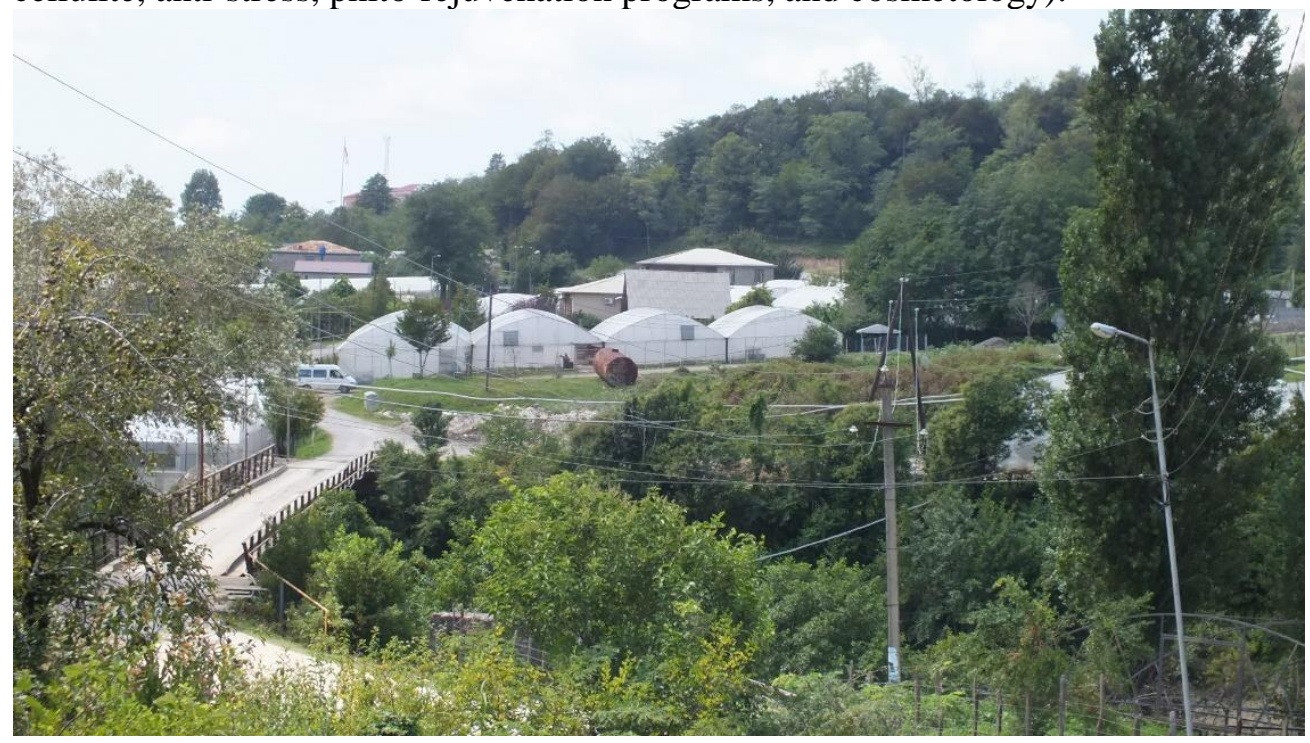

Fig. 3. Greenhouses in the resort Tsaishi, which utilize local thermal mineral waters

(photo by M. Tutberidze).

The very basic forms of resort service have changed as well: instead of pensions and sanatoriums with their medically trained personnel there are hotels of all kinds, where people with health problems live side by side with regular guests of different age, while medical treatment can be obtained at adjacent outpatient clinics, medical centers, balneal service centers or baths. There one can get all necessary information and recommendations regarding usage of resort resources for medical purposes (such service pattern was implied at a popular resort of Tsqaltubo since 1930-s). The majority of Georgian resorts face many problems nowadays. Resort infrastructure was partially destroyed in this country during the crisis of the 1990-s and the civil war. Refugees from the territories occupied by Russia were accommodated in what remained of buildings that used to comprise a luxury resort, which resulted in their further amortization. Restoration of the tourist objects infrastructure began in the 2000s. Partially, the accommodation capacity of old resorts was restored; at the same time, new buildings for tourist accommodation are under construction (map). The Georgian resorts can be subdivided into several categories, according to the state of preservation of their infrastructure (with the exception of those in the territory of Abkhazia and Tskhinvali region that are temporarily outside Georgian jurisdiction): 


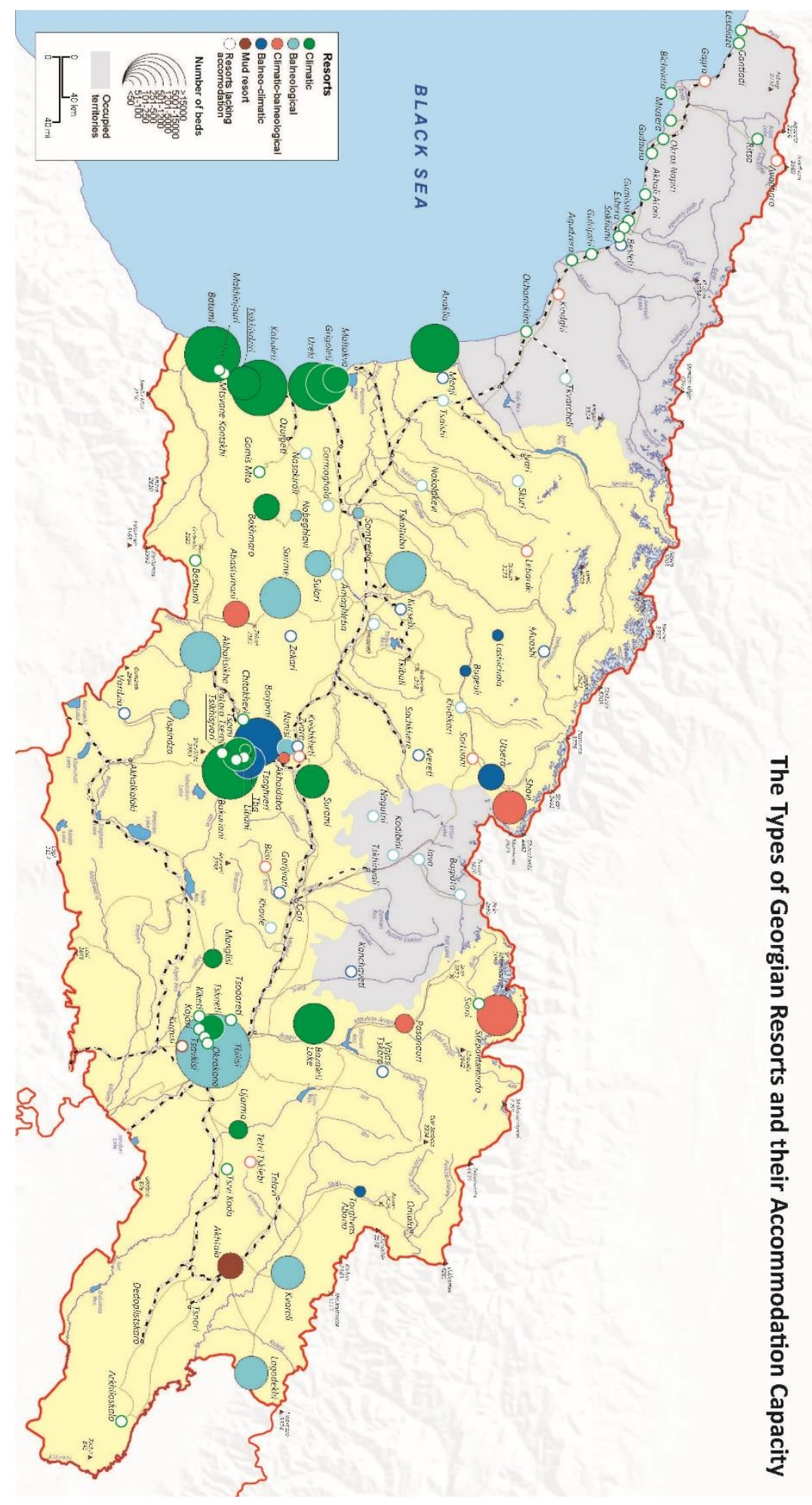


1.The resorts where after the economic crisis of the 90-s the hotel infrastructure was restored, renovated and advanced and that nowadays work full power approximately 25 of them, such as the Black Sea resorts, Tbilisi and its suburban resorts and resorts of Borjomi group as well as Sairme and Tsqaltubo resorts.

2. Resorts with the partially restored hotel infrastructure, those where restoration process continues, and those that have opportunities for development. There are about 15 such resorts, among them - Abastumani that is rapidly developing, due to both governmental and private investments; Bakhmaro, which is successfully developing, in accordance with the approved general plan; Ujarma and Nunisi have attracted attention of private investors.

3. Resorts that accommodate guests only periodically, mainly during tourist season. Their hotel infrastructure is of a low quality as a rule, and the only customers are local population. There are ten such resorts, namely, Sulori, Bugeuli, Torghva bath, Lashichala.

4. Resorts with completely destroyed hotel infrastructure whose restoration is not planned for the nearest future, while their natural resources, such as mineral water is utilized for other purposes (as in Tsaishi and Menji, for example - in greenhouses). This group is most numerous (up to 30 resorts) and includes such well-known for Georgian population sites as Menji, Tsaishi, Nabeghlavi, Zvare, Zekari, Skuri, Lebarde and others.According to the data of the Georgian National Tourism Administration at the beginning of 2020 which we completed during our field research, total accommodation capacity of the Georgian resorts (excluding Abkhazia and Tskhinvali region), approximates 75 thousand beds which is significantly less than the maximum rate of the 80 -s (almost 40 percent). However, today this amount represents 75 percent of the total carrying capacity in this country which in our opinion indicates the degree of attractiveness of the resorts. The accommodation capacity's 69.3percent belongs to hotels, 12.6percent to family houses. Besides, there are guest houses, hostels, etc. In Tsemi, Shekvetili and Tsqaltubo only 4 sanatoriums are left, with the total accommodation capacity of 500 bed-places. Just as expected, the largest concentration of accommodation capacity is in Tbilisi (the capital and a balneological resort at the time)-25.2 thousand beds, with Batumi and Bakuriani as co-runners lagging significantly behind (14.1 thousand and 10.0 thousand beds consequently). These figures, however, do not reflect the real situation at the resorts. The data base is volatile and incomplete. It should also be noted that vacationers at resorts actively use private housing stock.

An important issue is that of determining whether certain resorts were appropriately given this status, for it necessarily implies the existence of infrastructure, along with natural resources. At the same time, some resort areas (defined by the law as an area containing natural healing resources, suitable for targeted exploitation and not having relevant buildings) fully meet the requirements for a resort and have long functioned as such (Gonio, Kvariati, Chakvi, Shekvetili, Sioni and other) (Neidze at al. 2017). Total carrying capacity of such sites exceeds 7 thousand bed-place. Mountain ski centers, such as Gudauri, Tetnuldi, Goderdzi have significant wellness potential. Gudauri stands out for its accommodation capacity (up to three thousand beds). 
Regarding public demand for the wellness tourism, it should be noted that the population of Georgia that has a long tradition of recreation and treatment at the domestic resorts, due to infrastructure malfunctioning and low solvency, prefers vacations with rural relatives or in villages, there are from. Thus, in case quality and to the budget tour product is offered, Georgian population is prepared to go to local resorts. According to the National Tourism Administration research, in 2019 only 8.8 percent of the tourists - this country's citizens traveled for health treatment and wellness purposes (10.3percent in 2015), and 9.7 percent traveled for entertainment, rest and recreation (in 2015- 7,6percent).

In regard of the inbound tourism, the lack of information about Georgian resorts in the international market, together with low level of infrastructure competitiveness is a major hindrance. In 2019, only 1.8percent of foreign tourists came to Georgia for health rehabilitation and wellness purposes. The amount of those coming for rest, entertainment and recreation has risen for 11,6 percent in comparison with 2015 and makes 43,0percent of travelers (https://gnta.ge/statistics).

Assessing the current state of resorts, we cannot ignore the coronavirus pandemic, which has hampered economy development, tourism industry including, worldwide. International tourist arrivals were down 56percent globally from January to March, compared to 2019, according to the UN's World Tourism Organization (Ihttps://www.weforum.org/agenda/2020/09). It is too early to try to assess all the consequences of the pandemic. However, the impressive advancement of tourism, Georgia has achieved in recent years is at stake. Currently, when part of the resort accommodation capacity is used for quarantine purposes, only domestic tourism is allowed, in accordance with special regulations. After the end of the pandemic, the demand for health tourism is likely to increase.

Georgia's natural conditions and developing resort economy make it possible that wellness tourism become a priority kind of tourism, which, systematically, will attract high-spending tourists to the country.

\section{Conclusion}

1 The legal framework has to be changed, and the list of resorts and resort areas approved by the government decree needs to be revised;

2. Infrastructure development in Georgian resorts and further diversification of tourism products will attract to the country wellness tourism consumers;

3. Since wellness tourism is available almost all year round, it will alleviate the seasonality of the resorts;

4. Insurance companies and public sector of the economy should be actively involved, in order to meet the needs of the population in health tourism, considering economic opportunities of the Georgian population;

5 . The quality of the services rendered should be brought into correlation with the fees charged. Besides, there is lack of qualified personnel;

6 . The resort management system has to be improved, for which certain measures are being implemented. 


\section{References}

Baklykov L. I, 2003.Kurortnii turizm v sovremennikh usloviiakh. "Aktualnie problemi vosstanovitelnoi medicini, balbneologii I fizioterapii”.Moskva. [Resort Tourism in Modern Conditions] // "Current Problems of Restorative Medicine, Balneology and Physiotherapy", Moscow. Materials of the International congress "Zdravnitsa-2003" (Kislovodsk, October 14-17, 2003) (in Russian).

Dracheva E.L.2008 K voprosu o kurortovedenii I rekreacionnom turizme. [On the Issue of Resort Studies and Recreational Tourism/In: Tourism and Recreation on the Path of Sustainable development. The Soviet Sport publishing house. Moscow. (in Russian).

Dracheva E,1. 2016 Specialnie vidi turizma. Medicinskii turizm [Special Kinds of Tourism. Medical Tourism], publishing house "Knorus". Moscow. (in Russian).

GWI Global Wellness Tourism Economy. 2018

Neidze V, Pavliashvili N, Tutberidze M. 2017. Sakurorto turizmis ganvitarebis tendenciebi saqartveloshi [Resort Tourism Development Trends in Georgia], magazine: "Science and Technologies" \#2, p. publishing house "Technical University", Tbilisi (in Georgian).

Nikitina O.A.2012 Upravlenie formirovaniem integrirovannikh sanatorno-kurortnikh kompleksov v regione [Managing the Formation of Integrated Sanatorium-Resort Complexes in the Region]. Saint Petersburg (in Russian).

Rekreacionnie resursi I problemi ikh osvoenia.1991. [Recreational resources and the problems of their explotation]. $1991 \mathrm{In}$ : Natural resources of Georgia and the problems of their explotation., publishing house "Mecniereba", Tbilisi. (in Russian).

Tourism in Russia: A management handbook.2015 Publisher: Emerald. Editors: Frederic Dimanche, Lidia Andrades.

https://www.unwto.org/high-level-forum-medical-and-health-tourism

https://www.researchgate.net/figure/Interrelatedness-of-health-spa-wellness-and-medical$\underline{\text { tourism- }}$

https://gnta.ge/statistics/

https://www.unwto.org/high-level-forum-medical-and-health-tourism)/

htt/ps: www.weforum.org/agenda/2020/09

Saqartvelos mtavrobis brzdzanebuleba № 428, 3 ivlisi, 2014, Tbilisi, "saqartvelos

kurortebisa sa sakurorto adgilebis nusxa”, [Edict of the Goverment of Georgia № 428, 3

July 2014, Tbilisi, "About the List of Resorts and Resorts Places of Georgia"], (in Georgian). 